\title{
Significance of sedimentation and grazing by ice micro- and meiofauna for carbon cycling in annual sea ice (northern Baffin Bay)
}

\author{
Christine Michel $^{1, *}$, Torkel Gissel Nielsen ${ }^{2}$, Christian Nozais $^{3}$, Michel Gosselin ${ }^{3}$ \\ ${ }^{1}$ Freshwater Institute, Fisheries and Oceans Canada, 501 University Crescent, Winnipeg, Manitoba R3T 2N6, Canada \\ ${ }^{2}$ National Environmental Research Institute, Department of Marine Ecology, Frederiksborgvej 399, PO Box 358, \\ 4000 Roskilde, Denmark
}

${ }^{3}$ Institut des sciences de la mer de Rimouski (ISMER), Université du Québec à Rimouski, 310 allée des Ursulines, Rimouski, Québec G5L 3A1, Canada

\begin{abstract}
The fate of first-year ice algae production was assessed from April to June 1998, in the North Water Polynya. A landfast ice station was regularly visited and sampled for biomass, composition, and production of bottom ice algae, composition and grazing of the bottom ice meiofauna, and under-ice sedimentation. The latter was assessed using particle interceptor traps, which were installed at $1 \mathrm{~m}$ underneath the ice. The composition, carbon biomass and grazing of the bottom ice microfauna were also assessed at various stations within the polynya. A carbon budget for ice production and export, including meio- and microfauna grazing and sedimentation, was calculated based on 2 independent estimates. At the landfast ice station, the ice algae community was strongly dominated by pennate diatoms, with Nitzschia frigida averaging $85 \%$ of total cell numbers. The biomass of microheterotrophs and microautotrophs was less than $1 \%$ of total bottom ice carbon at the stations visited. Heterotrophic dinoflagellates and ciliates dominated the bottom ice microfauna community. Size-frequency distributions for the dominant ciliates (Strombidium spp. and hypotrichs) and dinoflagellates suggest that only the latter were able to utilise ice diatoms as a food resource. There was good agreement between carbon budget estimates and results showed that very little ice algal production was channelled through the meio- and microfauna within the ice. The bulk of the bottom ice carbon biomass was readily exported to the water column through direct sinking (75\% of ice export). These results stress that the main flow of organic carbon at the ice-water interface was through sedimentation of ice algae and suggest that food-web interactions within the ice do not influence the availability of ice algae to pelagic grazers, in seasonally ice covered areas.
\end{abstract}

KEY WORDS: Protists · Dinoflagellates $\cdot$ Ciliates $\cdot$ Sedimentation $\cdot$ Carbon cycling $\cdot$ Sea ice $\cdot$ Ice algae Resale or republication not permitted without written consent of the publisher

\section{INTRODUCTION}

Seasonal sea ice plays a significant role in the carbon cycle of polar ecosystems. Sea ice supports a diverse biological community including heterotrophic bacteria (e.g. Mathot et al. 1991, Haecky \& Andersson 1999), ice algae (see Horner et al. 1992), protozoans (e.g. Gradinger et al. 1991, 1992, Buck et al. 1998), as well

*Email: michelc@dfo-mpo.gc.ca as metazoans (e.g. Tanimura et al. 1996, SchnackSchiel et al. 2001). In the Arctic, ice algae can reach very high biomass (e.g. Smith et al. 1988) and primary production in sea ice is believed to account for 10 to $25 \%$ of the total annual production (Legendre et al. 1992), a value which should probably be revised upward (Gosselin et al. 1997). Many studies have focussed on bottom-up control of primary production in Arctic first-year ice, especially the role of light and nutrients (e.g. Gosselin et al. 1985, Cota et al. 1987, 
Michel et al. 1988, Mock \& Gradinger 2000). However, the role of grazers in the cycling of carbon in ice communities has, so far, received less attention (Vézina et al. 1997).

In the Arctic, the importance of ice algal production for under-ice amphipods and metazooplankton grazers has been reported, based on both direct (Conover et al. 1986a, Runge \& Ingram 1988, Werner 1997) and indirect (Michel et al. 1996, Scott et al. 1999, 2001) assessments. Results from an annual study in West Greenland also suggest that ice algae could serve as food for pelagic protozoans (Levinsen et al. 2000). With regard to grazing within the ice, previous work on meiofauna in annual Arctic sea ice generally suggest that a minor fraction of ice algae production is cycled through this

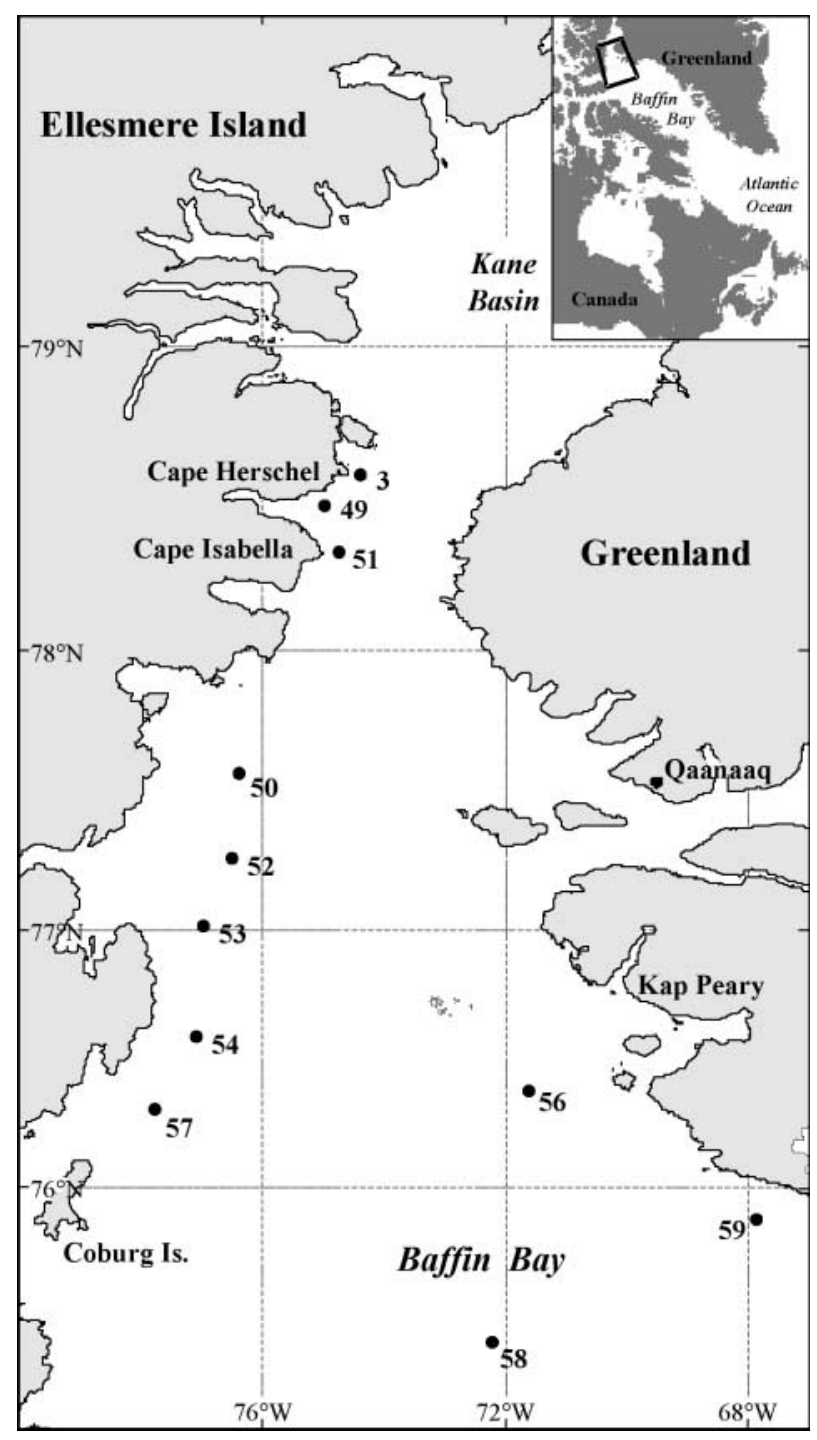

Fig. 1. Location of the ice sampling stations in the North Water, in spring 1998. Stn 3 is the time-series station at Cape Herschel pathway (Gradinger 1999, Nozais et al. 2001). However, grazing by meiofauna can control biomass accumulation in Greenland pack ice in summer (Gradinger et al. 1999). Studies on ice microheterotrophs have focussed primarily on the composition of the assemblage rather than on potential grazing impact (Grainger et al. 1985, Sime-Ngando et al. 1997, Buck et al. 1998, Gradinger et al. 1999, Song \& Wilbert 2000, Schnack-Schiel et al. 2001). In the Canadian Arctic Archipelago, estimates of microheterotrophs grazing in the sea ice suggest insignificant carbon flow through this pathway during spring (Vézina et al. 1997). To our knowledge, the combined effect of microfauna (heterotrophic dinoflagellates and ciliates) and meiofauna grazing in the bottom ice has not previously been assessed.

Annual sea ice provides a unique environment where the cycling of carbon is relatively constrained in time and space. Primary production that is not grazed in the bottom ice accumulates there until it is released into the water column, where it can be exploited by pelagic grazers (Michel et al. 1996) or potentially seed the later phytoplankton bloom (Kuosa et al. 1992, Haecky et al. 1998). Although all the material incorporated in the ice matrix will ultimately be released into the water column during ice melt, only the proportion of biomass that has not been utilised in situ is readily available for direct transfer to zooplankton grazers. Thus, trophic interactions within the ice influence the fate of the ice algal production after its release into the water column and its transfer to higher trophic levels.

The present study investigates the fate of ice production in the North Water (NOW) region by simultaneously assessing grazing within the ice matrix and sedimentation to the water column. We present data on the composition and abundance of microheterotrophs in the bottom ice and evaluate their role, as well as that of the ice meiofauna, in the export of bottom ice production.

\section{MATERIALS AND METHODS}

Sampling was conducted in the NOW, northern Baffin Bay, on board the CCGS 'Pierre Esprit Radisson', during the spring and early summer of 1998 (Fig. 1). The NOW is located at the northern extremity of Baffin Bay, to the south of Kane Basin. The NOW polynya typically opens in February and owes its existence to an ice bridge forming in Smith Sound which prevents ice drifting southerly from the Arctic Basin from entering the polynya (Dunbar 1969). Circulation in the polynya is complex due to the influence of different water masses. Basically, Arctic water flows southerly on the western side of the NOW, along Ellesmere Island, and 
Atlantic water flows northerly along the Greenland coast. The circulation and extent of different water masses in the polynya is well described in Melling et al. (2001) and Tremblay et al. (in press).

A landfast ice station located along the coast of Ellesmere Island (Stn 3, Fig. 1) was regularly visited, from 13 April to 9 May, for sampling of bottom ice algal biomass and production, bottom ice meiofauna, and under-ice sedimentation. The bottom ice community studied in this paper corresponds to the interstitial community described by Horner et al. (1992). The sampling at this station ended when the land fast ice detached, on 9 May, leaving the station adrift. On each sampling date, snow depth and ice thickness were measured and a total of 5 to 8 cores were taken for further analyses. From 3 to 5 cores were used for measurements of particulate organic carbon (POC), pigments, ice algal production, and cell identification and counts. Additional cores were used for meiofauna abundance and composition, as described below and detailed in Nozais et al. (2001). The ice cores were taken with a MARK II coring system $(9 \mathrm{~cm}$ inner diameter; Kovacs Entreprise). This method can entail some sample loss during collection, so that biomass values represent minimum estimates. The bottom 2 to $4 \mathrm{~cm}$ of each core, where most of the biomass was observed, was immediately cut and put in a dark isothermal container for transportation back to the ship. Surface seawater collected at the time of sampling was filtered through $0.22 \mu \mathrm{m}$ Durapore membrane filters and added to the cores to minimise osmotic stress during melting (Garrison \& Buck 1986).

Under-ice sedimentation at the landfast ice station was assessed using particle interceptor traps deployed $1 \mathrm{~m}$ below the undersurface of the ice. The traps were Plexiglas cylinders, $10 \mathrm{~cm}$ diameter, with an aspect ratio of 7. Upon recovery, the total volume of the traps was transferred to a dark container and brought back to the ship for analyses. The traps were rinsed and filled with Whatman GF/F filtered seawater prior to redeployment. The collection intervals ranged from 3 to $10 \mathrm{~d}$. No poison or preservative was added to the traps, which might have incurred some degradation of organic material within the traps. After pre-screening the trap volume through a $500 \mu \mathrm{m}$ mesh to remove large swimmers, trap subsamples were analysed for pigments, POC, and cell and faeces enumeration and counts, as described below.

Particulate ice-algae production was measured using the ${ }^{14} \mathrm{C}$-assimilation method described by Lee et al. (2001) and Nozais et al. (2001). Chlorophyll a (chl a) and pheopigments were determined fluorometrically on duplicate subsamples filtered on Whatman GF/F filters and extracted in $90 \%$ acetone for $24 \mathrm{~h}$ at $5^{\circ} \mathrm{C}$ in the dark. The concentrations of pigments were estimated according to the method of Parsons et al. (1984), after reading fluorescence on a 10-005R Turner Designs fluorometer. POC was measured on precombusted Whatman $\mathrm{GF} / \mathrm{F}$ filters, which were kept frozen at $-80^{\circ} \mathrm{C}$ until analysis on a Perkin-Elmer CHN analyser, model 2400. Algal cells and faeces enumeration were performed using an inverted microscope, on samples preserved in Lugol's solution. Cell sizes were determined for the most abundant species and volumes were estimated using appropriate geometric equations. Total cell volumes were converted into carbon using equations of Menden-Deuer \& Lessard (2000). Intact and fragments of faecal pellets were counted and sized, and total faeces volume was estimated. Faeces carbon biomass was calculated using a conversion factor of $0.057 \mathrm{mg} \mathrm{C} \mathrm{mm}^{-3}$ (González et al. 1994).

Details on the sampling and analyses for bottom ice meiofauna are given in Nozais et al. (2001). In brief, the bottom $6 \mathrm{~cm}$ of 2 to 3 ice cores was cut into $2 \mathrm{~cm}$ sections, which were transported back to the ship. The core sections were melted in $1 \mathrm{l}$ of surface water filtered onto $0.22 \mu \mathrm{m}$ Durapore membrane filters. Sea ice meiofauna was identified and counted under a dissecting microscope after staining in Rose Bengal samples sieved onto a $63 \mu \mathrm{m}$ and preserved with $4 \%$ boratebuffered formaldehyde solution. Ingestion rates were estimated using allometric equations (Moloney \& Field 1989) after conversion of meiofauna abundance into carbon, using appropriate equations for each group (see Nozais et al. 2001).

From 7 to 27 June, additional ice stations located within the polynya were sampled to determine the biomass of bottom ice algae (i.e. diatoms and naked flagellates), dinoflagellates and ciliates in bottom ice. For simplicity, autotrophic and heterotrophic dinoflagellates and ciliates in bottom ice are hereafter referred to as protists, while heterotrophs are referred to as ice microfauna. The sampling procedure was the same as described above, i.e. 3 to 5 cores were taken with the ice corer and allowed to slowly melt in $0.22 \mu \mathrm{m}$ filtered surface seawater. The samples were fixed in $2 \%$ Lugol's acid (final conc.) and counted using inverted microscopy (Utermöhl 1958).

Identification of ciliates to species or morphotypes was based on Foissner (1984), Small \& Lynn (1985), Lynn \& Montagnes (1988), Lynn et al. (1988), Montagnes et al. (1988), Krainer \& Foissner (1990), Montagnes \& Lynn (1991), Agatha et al. (1993) and Petz et al. (1995). All organisms were measured and distributed within size groups. The dinoflagellates $>20 \mu \mathrm{m}$ were identified using Dodge (1985), Thomsen (1992) and Tomas (1997). Unidentified spherical to subspherical gyrodinoid and gymnodinoid dinoflagellates were distributed into size classes. Epifluorescence microscopy was used to estimate the ratios between auto- 
Table 1. General characteristics of the ice stations in the North Water. Stn 3: time-series station at Cape Herschel. NA: data not available. POC: particulate organic carbon

\begin{tabular}{|c|c|c|c|c|c|c|c|c|c|}
\hline $\begin{array}{l}\text { Date } \\
\text { (1998) }\end{array}$ & $\begin{array}{c}\text { Ice } \\
\text { station }\end{array}$ & $\begin{array}{l}\text { Latitude } \\
\text { (N) }\end{array}$ & $\begin{array}{l}\text { Longitude } \\
\text { (W) }\end{array}$ & $\begin{array}{l}\text { Ice } \\
\text { type }\end{array}$ & $\begin{array}{l}\text { Snow } \\
\text { depth } \\
(\mathrm{cm})\end{array}$ & $\begin{array}{c}\text { Ice } \\
\text { thickness } \\
(\mathrm{cm})\end{array}$ & $\begin{array}{c}\text { Bottom ice } \\
\text { chl } a \\
\left(\mathrm{mg} \mathrm{m}^{-2}\right)\end{array}$ & $\begin{array}{c}\text { Bottom ice } \\
\text { POC } \\
\left(\mathrm{mg} \mathrm{m}^{-2}\right)\end{array}$ & $\begin{array}{c}\text { Bottom ice } \\
\text { production } \\
\left(\mathrm{mg} \mathrm{C} \mathrm{m}^{-2} \mathrm{~d}^{-1}\right)\end{array}$ \\
\hline $13 \mathrm{Apr}$ & $3 \mathrm{~A}$ & $78^{\circ} 35.9^{\prime}$ & $74^{\circ} 29.4^{\prime}$ & Land fast & 3.0 & 155 & 11.6 & 616 & 68 \\
\hline $16 \mathrm{Apr}$ & $3 B$ & $78^{\circ} 35.9^{\prime}$ & $74^{\circ} 29.4^{\prime}$ & Land fast & 3.4 & 155 & 19.5 & 672 & 84 \\
\hline $26 \mathrm{Apr}$ & $3 C$ & $78^{\circ} 35.9^{\prime}$ & $74^{\circ} 29.4^{\prime}$ & Land fast & 5.2 & 155 & 18.5 & 865 & 153 \\
\hline 01 May & $3 \mathrm{D}$ & $78^{\circ} 35.9^{\prime}$ & $74^{\circ} 29.4^{\prime}$ & Land fast & 6.8 & 150 & 5.2 & 231 & 38 \\
\hline 07 Jun & 49 & $78^{\circ} 25.3^{\prime}$ & $75^{\circ} 10.8$ & Land fast & 17.0 & 153 & 3.4 & 364 & 22 \\
\hline 10 Jun & 50 & $77^{\circ} 48.8^{\prime}$ & $76^{\circ} 22.2^{\prime}$ & Land fast & 10.0 & 192 & 25.4 & 2108 & 134 \\
\hline 13 Jun & 51 & $78^{\circ} 16.0^{\prime}$ & $74^{\circ} 36.0^{\prime}$ & Land fast & 6.3 & 166 & 9.7 & 603 & 68 \\
\hline 13 Jun & 52 & $77^{\circ} 21.0^{\prime}$ & $76^{\circ} 35.2^{\prime}$ & Land fast & 8.7 & 127 & 1.2 & 121 & 5.4 \\
\hline 14 Jun & 53 & $77^{\circ} 0.1^{\prime}$ & $77^{\circ} 14.3^{\prime}$ & NA & 1.2 & 117 & 0.4 & 142 & 4.3 \\
\hline 15 Jun & 54 & $76^{\circ} 57.5^{\prime}$ & $77^{\circ} 19.3^{\prime}$ & Pack ice & 9.3 & 48 & 0.2 & 126 & 2.4 \\
\hline 20 Jun & 56 & $76^{\circ} 20.0^{\prime}$ & $71^{\circ} 49.2^{\prime}$ & Pack ice & 3.3 & 65 & 0.1 & 69 & NA \\
\hline 24 Jun & 57 & $76^{\circ} 23.0^{\prime}$ & $77^{\circ} 47.6^{\prime}$ & Land fast & 5.7 & 167 & 0.2 & 116 & NA \\
\hline 26 Jun & 58 & $75^{\circ} 35.1^{\prime}$ & $72^{\circ} 21.6^{\prime}$ & Pack ice & 3.8 & 56 & 0.2 & 75 & NA \\
\hline 27 Jun & 59 & $75^{\circ} 48.2^{\prime}$ & $67^{\circ} 57.5^{\prime}$ & Pack ice & 3.0 & 102 & 0.2 & 101 & NA \\
\hline
\end{tabular}

trophic and heterotrophic dinoflagellates, for size groups of $10 \mu \mathrm{m}$. The ratios were then applied, for each size class, to dinoflagellate counts from Lugol's-fixed samples to estimate the heterotrophic biomass. Protist volumes were estimated from linear dimensions using
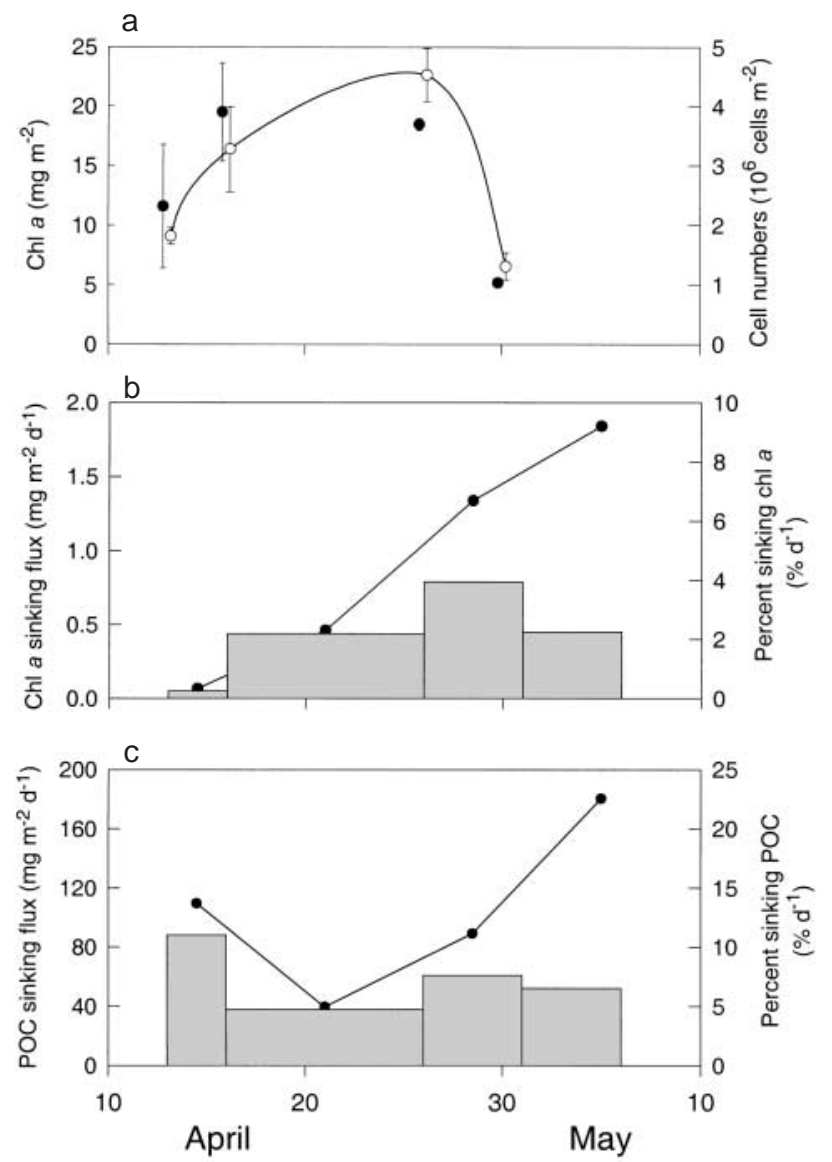

appropriate simple geometrical shapes, and converted to carbon biomass using the equations of MendenDeuer \& Lessard (2000). Community grazing for all microfauna groups was calculated from average cell volumes and standing stocks according to equations in Hansen et al. (1997). Microfauna grazing estimates were temperature corrected, according to a $Q_{10}$ of 2.8, and assumed a growth efficiency of 0.33 (Hansen et al. 1997).

\section{RESULTS}

The stations within the NOW region showed variable ice thickness and bottom ice biomass, although stations visited after mid-June consistently showed bottom ice chl $a$ and POC concentrations $<1$ and $<150 \mathrm{mg} \mathrm{m}^{-2}$, respectively (Table 1 ).

The time-series station at Cape Herschel showed a seasonal increase in bottom ice algal biomass during April, and a rapid decline in early May (Fig. 2a). This

Fig. 2. Seasonal trends in bottom ice biomass and under-ice sedimentation at Cape Herschel. (a) Bottom ice chl a (•) and algal cell abundances ( $\mathrm{O}$ and solid line). Values are averages for 2 or 3 sampling sites and vertical lines are standard deviations. For clarity, chl $a$ and cell numbers are positioned alongside the actual sampling day. (b) Chl a sinking flux at $1 \mathrm{~m}$ (bars) and percent daily sinking loss of bottom ice chl a (•). (c) Particulate organic carbon (POC) sinking flux at $1 \mathrm{~m}$ (bars) and percent daily sinking loss of bottom ice POC (•). Percent daily loss is estimated at mid sediment trap sampling interval, as the ratio between the sinking flux at $1 \mathrm{~m}$ and the average bottom ice biomass between 2 consecutive sampling dates, assuming constant ice biomass during the last sampling interval 


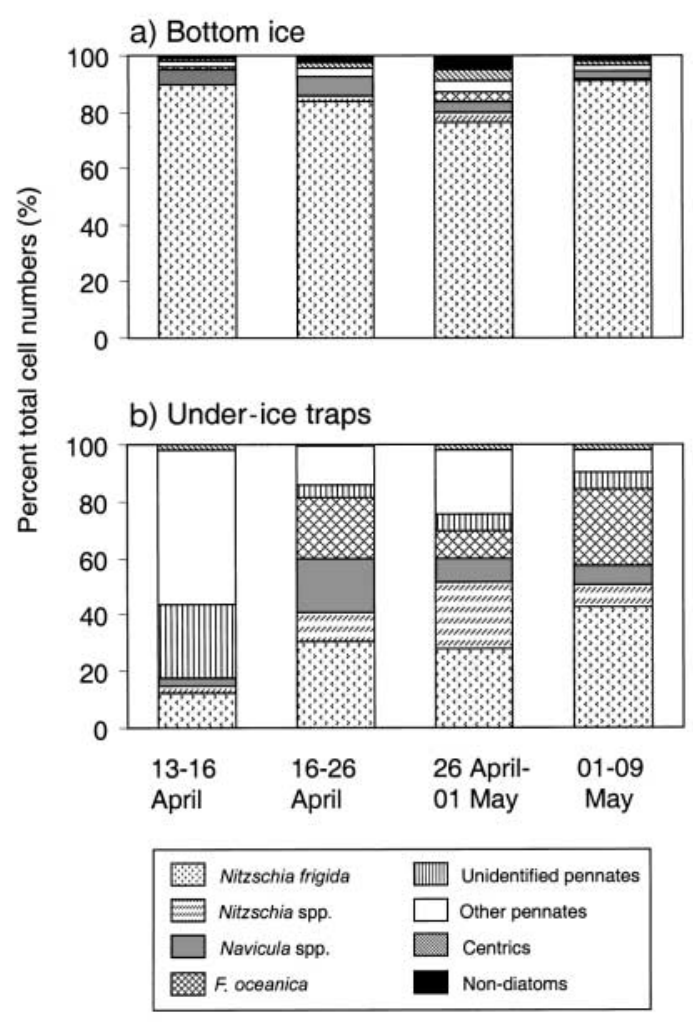

Fig. 3. Relative contribution of dominant algal species and groups to total cell numbers at Cape Herschel. (a) Bottom ice assemblage and (b) under-ice sediment trap assemblage. Values for bottom ice assemblage are averages for 2 or 3 sampling sites. Dates are sampling dates for ice algae and correspond to the beginning of trap sampling interval

general trend was evident in chl a concentrations and cell numbers (Fig. 2a), although there was generally higher variability among proximate sites during the first part of the season. The chl a sinking flux at $1 \mathrm{~m}$ below the ice remained $<1 \mathrm{mg} \mathrm{m}^{-2} \mathrm{~d}^{-1}$ throughout the season; yet, it increased by an order of magnitude after the first sampling interval (Fig. 2b). This increase in vertical flux induced a concomitant increase in the proportion of ice algal biomass exported daily through sinking. The percent daily sinking export of bottom ice algae continued to increase throughout the season, up to a maximum of ca. $10 \% \mathrm{~d}^{-1}$, reflecting changes in the ice algal biomass rather than further increase in sinking fluxes (Fig. 2a,b). POC sinking fluxes did not show any clear seasonal trend; they represented a daily downward export of bottom ice POC ranging from 5 to $22 \% \mathrm{~d}^{-1}$ (Fig. 2c).

The bottom ice algal assemblage at the landfast ice station was strongly dominated by pennate diatoms, which made up, on average, $95 \%$ of total cell numbers (range: 91 to $98 \%$ ). A single species, Nitzschia frigida, prevailed and contributed, on average, to $85 \%$ of total cell numbers (range: 76 to $91 \%$, Fig. 3a). The under-ice trap assemblage was also strongly dominated by pennate diatoms but the relative contribution of each species was different than that observed in the bottom ice (Fig. 3b). N. frigida made up a maximum of $43 \%$ of total cell numbers in the traps; however, there were high numbers of unidentified diatoms in the trap assemblages. Relative proportions of Navicula spp. and Fragilariopsis oceanica were much higher in the sinking biomass than in the ice. The trap assemblages also comprised significant numbers of Fossula arctica and Pleurosigma spp. (included as other pennates in Fig. 3b).

We did not estimate bottom ice protist abundance at the landfast ice station; however, their biomass contributed $<1 \%$ of bottom ice POC at the stations within the polynya, except for Stn 58 where protist carbon made up $3 \%$ of total bottom ice carbon (Table 2). Heterotrophic ciliates contributed more than $50 \%$ of total protist carbon biomass at all stations, except Stns 49 and 50. Dinoflagellates made up ca. $60 \%$ of the protist carbon at the former station, while Stn 50 showed an equal partition of protist carbon between dinoflagellates and ciliates (Table 2). Dinoflagellate carbon biomass was mainly accounted for by heterotrophs, except at Stn 49 where it was split almost equally between autotrophs and heterotrophs. At all stations, the autotrophic ciliate Mesodinium rubrum was present in very low numbers and made up a very small fraction of the protist biomass (Table 2). Overall, the bottom ice protist assemblage was strongly dominated by heterotrophs (Table 2). The relative contribution of heterotroph groups to the bottom ice microfauna is shown in Fig. 4. Ciliates made up $>50 \%$ of the microfauna carbon at all stations but they generally contributed a small fraction of individual abundances. Dinoflagellates, with variable proportions of thecate and athecate forms, generally dominated microfauna abundances but contributed little to carbon biomass. Size-frequency distributions for the dominant ciliates (Strombidium spp. and hypotrichs) and dinoflagellates are presented in Fig. 5. The size range for ciliates was broad (from ca. 20 to $200 \mu \mathrm{m}$ ), but maximum abundances were centred around 30 to $40 \mu \mathrm{m}$ for Strombidium spp. and 40 to $60 \mu \mathrm{m}$ for hypotrichs (Fig. 5a,b). For dinoflagellates, peak abundances were distributed within the 20 to $40 \mu \mathrm{m}$ size classes (Fig. 5c,d). Grazing estimates for the ice microfauna are shown in Table 3. At all stations, ice microfauna grazing was $\leq 1 \mathrm{mg} \mathrm{C}$ $\mathrm{m}^{-2} \mathrm{~d}^{-1}$.

Since sampling at the landfast ice station covered both periods of growth and decline of the ice algal biomass, it was possible to compute a carbon budget of production and export from the ice, based on the seasonal changes observed. Fig. 6 shows the potential 
Table 2. Protist carbon biomass $\left(\mathrm{mg} \mathrm{m}^{-2}\right)$ in the bottom ice. Values in parentheses correspond, for total protists, to the percent total ice POC and, for each group, to the percent protist carbon biomass. Values for Stn 50 are averages for 2 sampling sites

\begin{tabular}{|c|c|c|c|c|c|c|c|c|c|}
\hline Stn & $\begin{array}{c}\text { Total } \\
\text { protists }\end{array}$ & $\begin{array}{l}\text { Mesodinium } \\
\text { rubrum }\end{array}$ & $\begin{array}{l}\text { Heterotrophic } \\
\text { ciliates }\end{array}$ & Athecate & Thecate & $\begin{array}{c}\text { Dinoflagellate } \\
\text { Autotrophs }\end{array}$ & $\begin{array}{l}\text { es } \\
\text { Heterotrophs }\end{array}$ & Total & $\begin{array}{c}\text { Total } \\
\text { microfauna }\end{array}$ \\
\hline 49 & $\begin{array}{l}2.16 \\
(0.6)\end{array}$ & $\begin{array}{l}0.02 \\
(1.0)\end{array}$ & $\begin{array}{c}0.83 \\
(38.4)\end{array}$ & $\begin{array}{l}0.09 \\
(4.2)\end{array}$ & $\begin{array}{c}1.22 \\
(56.5)\end{array}$ & $\begin{array}{c}0.67 \\
(31.0)\end{array}$ & $\begin{array}{c}0.64 \\
(29.7)\end{array}$ & $\begin{array}{c}1.31 \\
(60.6)\end{array}$ & $\begin{array}{c}1.47 \\
(68.1)\end{array}$ \\
\hline 50 & $\begin{array}{l}4.06 \\
(0.2)\end{array}$ & $\begin{array}{l}0.05 \\
(1.2)\end{array}$ & $\begin{array}{c}2.02 \\
(49.7)\end{array}$ & $\begin{array}{c}0.45 \\
(11.2)\end{array}$ & $\begin{array}{c}1.53 \\
(37.8)\end{array}$ & $\begin{array}{l}0.05 \\
(1.2)\end{array}$ & $\begin{array}{c}1.94 \\
(47.9)\end{array}$ & $\begin{array}{c}1.99 \\
(49.08)\end{array}$ & $\begin{array}{c}3.96 \\
(97.6)\end{array}$ \\
\hline 51 & $\begin{array}{l}3.98 \\
(0.7)\end{array}$ & $\begin{array}{l}0.02 \\
(0.5)\end{array}$ & $\begin{array}{c}2.74 \\
(68.9)\end{array}$ & $\begin{array}{l}0.32 \\
(7.9)\end{array}$ & $\begin{array}{c}0.90 \\
(22.7)\end{array}$ & $\begin{array}{l}0.00 \\
(0.0)\end{array}$ & $\begin{array}{c}1.22 \\
(30.6)\end{array}$ & $\begin{array}{c}1.22 \\
(30.6)\end{array}$ & $\begin{array}{c}3.96 \\
(99.5)\end{array}$ \\
\hline 52 & $\begin{array}{l}0.52 \\
(0.4)\end{array}$ & $\begin{array}{l}0.00 \\
(0.0)\end{array}$ & $\begin{array}{c}0.28 \\
(54.2)\end{array}$ & $\begin{array}{l}0.01 \\
(1.6)\end{array}$ & $\begin{array}{c}0.23 \\
(44.1)\end{array}$ & $\begin{array}{l}0.02 \\
(4.1)\end{array}$ & $\begin{array}{c}0.22 \\
(41.7)\end{array}$ & $\begin{array}{c}0.24 \\
(45.8)\end{array}$ & $\begin{array}{c}0.50 \\
(95.9)\end{array}$ \\
\hline 53 & $\begin{array}{l}1.18 \\
(0.8)\end{array}$ & $\begin{array}{l}0.01 \\
(0.4)\end{array}$ & $\begin{array}{c}1.11 \\
(94.2)\end{array}$ & $\begin{array}{l}0.05 \\
(4.3)\end{array}$ & $\begin{array}{l}0.01 \\
(1.1)\end{array}$ & $\begin{array}{l}0.00 \\
(0.0)\end{array}$ & $\begin{array}{l}0.06 \\
(5.4)\end{array}$ & $\begin{array}{l}0.06 \\
(5.4)\end{array}$ & $\begin{array}{c}1.17 \\
(99.6)\end{array}$ \\
\hline 54 & $\begin{array}{l}0.86 \\
(0.6)\end{array}$ & $\begin{array}{l}0.00 \\
(0.0)\end{array}$ & $\begin{array}{c}0.57 \\
(66.1)\end{array}$ & $\begin{array}{l}0.05 \\
(5.5)\end{array}$ & $\begin{array}{c}0.24 \\
(28.4)\end{array}$ & $\begin{array}{l}0.00 \\
(0.0)\end{array}$ & $\begin{array}{c}0.29 \\
(33.9)\end{array}$ & $\begin{array}{c}0.29 \\
(33.9)\end{array}$ & $\begin{array}{l}0.86 \\
(100)\end{array}$ \\
\hline 56 & $\begin{array}{l}0.29 \\
(0.4)\end{array}$ & $\begin{array}{l}0.00 \\
(0.0)\end{array}$ & $\begin{array}{c}0.17 \\
(59.1)\end{array}$ & $\begin{array}{c}0.09 \\
(32.1)\end{array}$ & $\begin{array}{l}0.03 \\
(8.8)\end{array}$ & $\begin{array}{l}0.00 \\
(0.0)\end{array}$ & $\begin{array}{c}0.12 \\
(40.9)\end{array}$ & $\begin{array}{c}0.12 \\
(40.9)\end{array}$ & $\begin{array}{c}0.29 \\
(100)\end{array}$ \\
\hline 57 & $\begin{array}{l}0.56 \\
(0.5)\end{array}$ & $\begin{array}{l}0.00 \\
(0.0)\end{array}$ & $\begin{array}{c}0.53 \\
(94.7)\end{array}$ & $\begin{array}{l}0.02 \\
(2.8)\end{array}$ & $\begin{array}{l}0.01 \\
(2.5)\end{array}$ & $\begin{array}{l}0.00 \\
(0.0)\end{array}$ & $\begin{array}{l}0.03 \\
(5.3)\end{array}$ & $\begin{array}{l}0.03 \\
(5.3)\end{array}$ & $\begin{array}{c}0.56 \\
(100)\end{array}$ \\
\hline 58 & $\begin{array}{l}2.08 \\
(2.8)\end{array}$ & $\begin{array}{l}0.01 \\
(0.3)\end{array}$ & $\begin{array}{c}1.94 \\
(93.3)\end{array}$ & $\begin{array}{l}0.08 \\
(4.0)\end{array}$ & $\begin{array}{l}0.05 \\
(2.4)\end{array}$ & $\begin{array}{l}0.00 \\
(0.0)\end{array}$ & $\begin{array}{l}0.13 \\
(6.4)\end{array}$ & $\begin{array}{l}0.13 \\
(6.4)\end{array}$ & $\begin{array}{c}2.07 \\
(99.7)\end{array}$ \\
\hline 59 & $\begin{array}{l}0.87 \\
(0.9)\end{array}$ & $\begin{array}{l}0.00 \\
(0.0)\end{array}$ & $\begin{array}{c}0.77 \\
(88.1)\end{array}$ & $\begin{array}{c}0.10 \\
(11.7)\end{array}$ & $\begin{array}{l}0.00 \\
(0.3)\end{array}$ & $\begin{array}{l}0.00 \\
(0.0)\end{array}$ & $\begin{array}{c}0.10 \\
(11.9)\end{array}$ & $\begin{array}{c}0.10 \\
(11.9)\end{array}$ & $\begin{array}{c}0.87 \\
(100)\end{array}$ \\
\hline
\end{tabular}
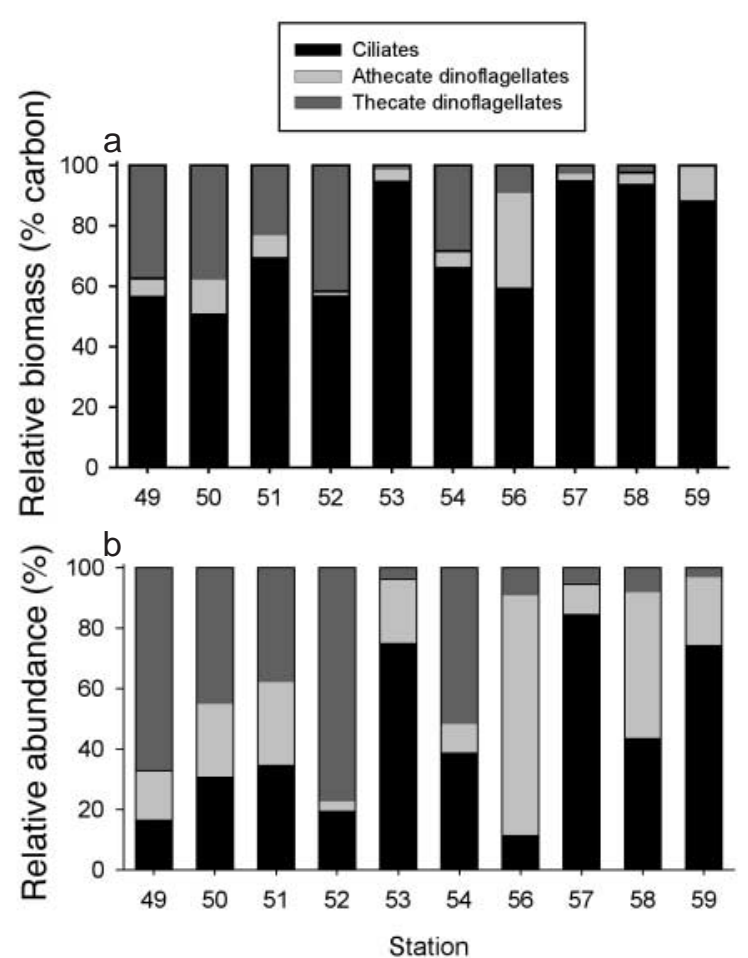

Fig. 4. Relative contribution of heterotrophic ciliates and dinoflagellates to (a) biomass and (b) abundance of bottom ice microfauna at stations within the North Water (NOW). Relative carbon biomass. Values for Stn 50 are averages for 2 sampling sites
POC build-up in bottom ice, the observed bottom ice POC, and under-ice POC sedimentation; all of which were used for the budget estimate. The budget is based on 2 independent estimates of export, according to the following equations:

$$
E_{\text {ice }}=\int_{t=0}^{t} P_{\text {ice }}(t) \partial t-B_{\text {(ice) }}(t)
$$

where $E_{\text {ice }}$ is the export of POC from the ice, in mg C $\mathrm{m}^{-2} ; P_{\text {ice }}(t)$ is the particulate production in bottom ice at time $t$, in $\mathrm{mg} \mathrm{C} \mathrm{m}^{-2} \mathrm{~d}^{-1}$; and $B_{\text {ice }}(t)$ is the botttom ice POC at time $t$, in $\mathrm{mg} \mathrm{C} \mathrm{m}^{-2}$ :

$$
E_{\text {ice }}=S_{\text {ice }}+\left(G_{\text {ice }}-S_{\text {faeces }}\right)
$$

where $S_{\text {ice }}$ is the sinking export of POC from the ice, in $\mathrm{mg} \mathrm{C} \mathrm{m}{ }^{-2}$ (Eq. 3); $G_{\text {ice }}$ is the grazing in bottom ice, in $\mathrm{mg} \mathrm{C} \mathrm{m}{ }^{-2}$ (Eqs. 4 to 7 ); and $S_{\text {faeces }}$ is the sinking export of faeces from the ice, in $\mathrm{mg} \mathrm{C} \mathrm{m} \mathrm{C}^{-2}$ (Eq. 8):

$$
S_{\text {ice }}=\sum_{t=0}^{t}\left(\text { Flux } \text { POC }_{1 \mathrm{~m}} \cdot \Delta t\right)
$$

where Flux $\mathrm{POC}_{1 \mathrm{~m}}$ is the sinking flux of POC obtained from traps installed at $1 \mathrm{~m}$ below the ice, in $\mathrm{mg} \mathrm{C}$ $\mathrm{m}^{-2} \mathrm{~d}^{-1}$.

$$
G_{\text {ice }}=G_{\mathrm{M}(\text { ice })}+G_{\mathrm{m}(\text { ice })}
$$

where $G_{\mathrm{M}(\mathrm{ice})}$ is the grazing by meiofauna in bottom ice, in $\mathrm{mg} \mathrm{C} \mathrm{m}^{-2}$ (Eq. 5, $G_{\mathrm{M} \text { (ice) }}(t)$ values for each sampling interval, in $\mathrm{mg} \mathrm{m}^{-2} \mathrm{~d}^{-1}$, in Nozais et al. 2001); and 

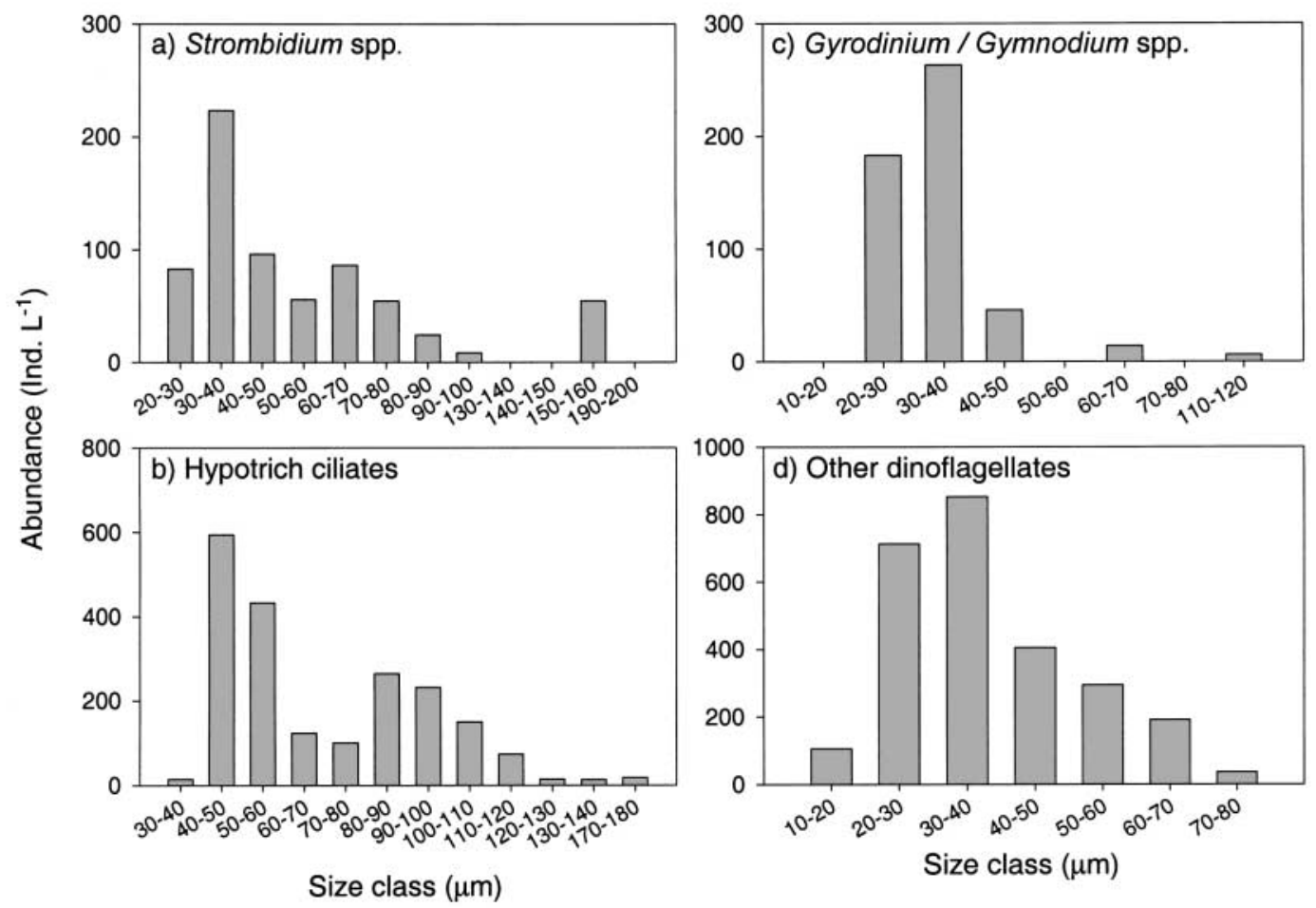

Fig. 5. Size-frequency distribution of dominant ciliates and dinoflagellates in the ice bottom, based on average abundances for all stations visited. (a) Strombidium spp., (b) hypotrich ciliates, (c) Gyrodinium and Gymnodium spp. and (d) other dinoflagellates

$G_{\mathrm{m}(i c e)}$ is the grazing by microfauna in bottom ice, in mg C m${ }^{-2}$ (Eq. 6).

$$
\begin{gathered}
G_{\mathrm{M}(\text { ice })}=\int_{t=0}^{t} G_{\mathrm{M}(\text { ice })}(t) \partial t \\
G_{\mathrm{m} \text { (ice) }}=\sum_{t=0}^{t}\left[\left(G_{\mathrm{m}^{*} \text { (ice) }} \times B_{\text {ice }}(t)\right) \Delta t\right]
\end{gathered}
$$

where $G_{\mathrm{m}^{*} \text { (ice) }}$ is the mean proportion of bottom ice carbon biomass grazed by microfauna, in $\mathrm{g}: \mathrm{g} \mathrm{d}^{-1}$, at 10 stations (Eq. 7); and $B_{\text {ice }}(t)$ is as in Eq. (1).

$$
G_{\mathrm{m}^{*} \text { (ice) }}=\overline{\left(\frac{G_{\mathrm{m} \text { (ice) }}(t)}{B_{\text {ice }}(t)}\right)}
$$

where $G_{\mathrm{m}(\mathrm{ice})}(t)$ are microfauna grazing estimates, in $\mathrm{mg} \mathrm{m}^{-2} \mathrm{~d}^{-1}$ (values in Table 3 ).

$S_{\text {faeces }}$ is the sinking export of faecal material from the ice, in $\mathrm{mg} \mathrm{C} \mathrm{m}^{-2}$, estimated from:

$$
S_{\text {faeces }}=\sum_{t=0}^{t}\left(\text { Flux POCfaeces }_{1 \mathrm{~m}} \cdot \Delta t\right)
$$

where Flux POCfaeces ${ }_{1 \mathrm{~m}}$ is the sinking flux of carbon explained by faeces, obtained from traps installed at $1 \mathrm{~m}$ below the ice, in $\mathrm{mg} \mathrm{C} \mathrm{m} \mathrm{m}^{-2} \mathrm{~d}^{-1}$.

Results from the budget estimate are presented in Table 4 . There is a good agreement between the 2 independent export estimates, and the value of ice carbon export calculated as the sinking flux at $1 \mathrm{~m}$ and the bottom ice grazing accounts for $79 \%$ of the potential export obtained from bottom ice production and biomass data. Table 4 shows that most of the bottom ice production is exported through sinking $(75 \%$ of $\left.P_{\text {ice }}-B_{\text {ice }}\right)$ and that bottom ice grazing represents a small fraction of the export. Accordingly, the sinking flux of faecal material remains small, although it is smaller than the grazing in bottom ice.

Table 3. Microfauna grazing in the bottom ice $\left(\mathrm{mg} \mathrm{C} \mathrm{m}^{-2} \mathrm{~d}^{-1}\right)$. Values for Stn 50 are averages for 2 sampling sites

\begin{tabular}{|lccc|}
\hline Stn & $\begin{array}{c}\text { Heterotrophic } \\
\text { dinoflagellates }\end{array}$ & Ciliates & $\begin{array}{c}\text { Total } \\
\text { microfauna }\end{array}$ \\
\hline 49 & 0.42 & 0.14 & 0.56 \\
50 & 0.56 & 0.45 & 1.01 \\
51 & 0.40 & 0.60 & 1.00 \\
52 & 0.08 & 0.06 & 0.14 \\
53 & 0.02 & 0.25 & 0.27 \\
54 & 0.10 & 0.14 & 0.24 \\
56 & 0.05 & 0.03 & 0.08 \\
57 & 0.01 & 0.14 & 0.15 \\
58 & 0.06 & 0.37 & 0.43 \\
59 & 0.03 & 0.15 & 0.18 \\
\hline
\end{tabular}


Table 4. Carbon budget for bottom ice particulate carbon export at a landfast ice station in the North Water, during April and May. Numbers in parentheses refer to the equation used for the computations

\begin{tabular}{|c|c|c|c|c|c|c|c|}
\hline & \multirow{3}{*}{$\begin{array}{l}\text { Potential ice } \\
\text { export (1) }\end{array}$} & \multirow{3}{*}{ Total (2) } & \multicolumn{5}{|c|}{ Estimated ice export (2) _ } \\
\hline & & & \multicolumn{2}{|c|}{ Sinking $(2)$} & \multicolumn{3}{|c|}{ Bottom ice grazing (5) } \\
\hline & & & Total POC (3) & Faeces POC (8) & Total (4) & Meiofauna (6) & Microfauna (7) \\
\hline $\mathrm{mg} \mathrm{C} \mathrm{m} \mathrm{m}^{-2}$ & 1814 & 1438 & 1365 & 26.2 & 72.5 & 47.4 & 25.1 \\
\hline$\%$ potential export & 100 & 79.2 & 75.2 & 1.4 & 4.0 & 2.6 & 1.4 \\
\hline
\end{tabular}

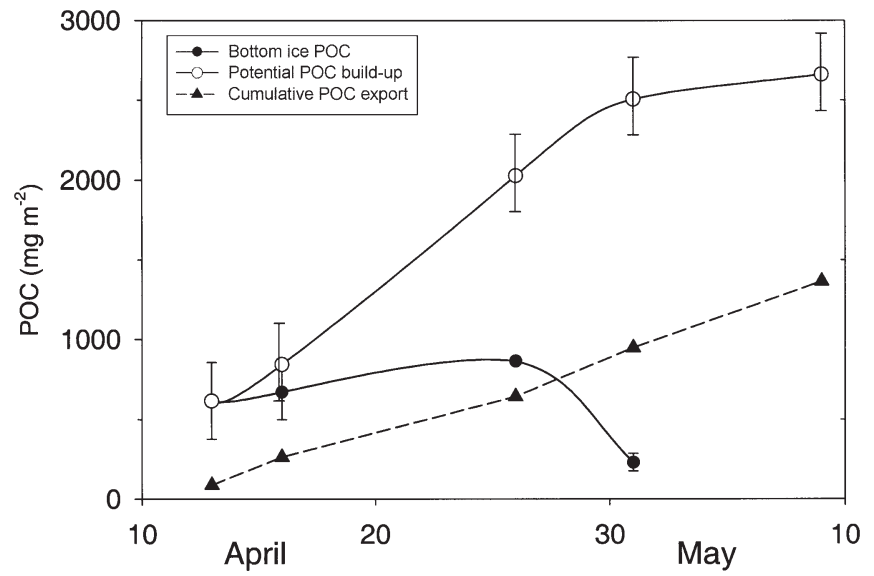

Fig. 6. Seasonal changes in bottom ice POC and POC potential build-up, and cumulative sedimentation of POC from the ice, during April and May at Cape Herschel. POC potential build-up is estimated by integrating particulate ice algal production during each sampling period, assuming that production was null at the end of the last trap sampling interval

\section{DISCUSSION}

The biomass of ice algae at the landfast ice station of the NOW was rather low (ca. 5 -to $10 \mathrm{mg} \mathrm{m}^{-2}$ ) compared to values reported for the Resolute Passage area (range: 20 to $250 \mathrm{mg} \mathrm{m}^{-2}$, Cota et al. 1987, 1991, Smith et al. 1988, Michel et al. 1996), but was comparable to values for land fast-ice in Frobisher Bay (Grainger 1977, Hsiao 1992), both areas being in the vicinity of the NOW. The composition of the land fast-ice algal community was strongly dominated by pennate diatoms, both by numbers ( $>91 \%$ of total cell numbers, Fig. 3a) and carbon contribution $(>88 \%$, results not shown). This is in agreement with other studies in surrounding land fast-ice areas in the Arctic (e.g. Cross 1982, Hsiao 1992, Michel et al. 1996).

Temporal changes in chl a and algal cell concentrations at the landfast ice station correspond to the spring cycle of ice algal growth and decline associated with ice melt. Similar seasonal trends have been observed in Resolute Passage (Anning 1989, Michel et al. 1996), although the timing of the ice algal decline appears to have occurred earlier in the NOW. Sinking fluxes of chl a $\left(<1 \mathrm{mg} \mathrm{m}^{-2} \mathrm{~d}^{-1}\right)$ and POC $\left(<100 \mathrm{mg} \mathrm{m}^{-2} \mathrm{~d}^{-1}\right)$ under the ice are within the range of under-ice values reported for surrounding land fast-ice areas (0.6 to $2 \mathrm{mg}$ chl a m${ }^{-2} \mathrm{~d}^{-1}$ in Frobisher Bay, Hsiao 1987; 0.1 to $2.4 \mathrm{mg}$ chl a m${ }^{-2} \mathrm{~d}^{-1}$ in Resolute Passage, Michel et al. 1996).

The grazing estimates by the ice meio- and microfauna show that the grazing pressure by the 2 groups of grazers was low in the bottom ice and accounted for $4 \%$ of the potential particulate export. The bottom ice meiofauna at the landfast ice station was largely dominated by nematodes (96\% by numbers, Nozais et al. 2001). This agrees with results from previous studies which showed dominance of nematodes in Arctic land fast-ice (e.g. Pond Inlet: Cross 1982, Carey 1985; Stefanson Sound: Carey \& Montagna 1982; Frobisher Bay, Grainger et al. 1985). For nematodes, possible food items include diatoms (Grainger \& Hsiao 1990), bacteria and protozoans (Gradinger \& Zhang 1997), and dissolved organic matter (Moens \& Vincx 2000). The ice microfauna was dominated by dinoflagellates and ciliates. From a grazing perspective, these 2 groups behave differently. Ciliates mainly predate on prey ca. $1: 10$ of their cell volume while dinoflagellates have a 1:1 predator:prey ratio (Hansen et al. 1994). The dominant size classes of heterotrophic dinoflagellates were between 20 and $40 \mu \mathrm{m}$, suggesting that they were able to utilise ice diatoms, which were mainly pennates with apex length $>30 \mu \mathrm{m}$, as a food resource. Ciliates can also feed on diatoms; however, the maximum prey size for naked and loricate oligotrich ciliates is ca. $45 \%$ of their oral diameter (Heinbokel 1978, Jonsson 1986). The dominant ciliates in the ice were Strombidium spp. ranging in size between 30 and $40 \mu \mathrm{m}$ followed by hypotrichs, for which the most abundant size range was between 40 and $60 \mu \mathrm{m}$. Larger size classes were observed but were less abundant (see Fig. 5). Hence, the most abundant ice diatoms at the landfast ice station (apex length $>30 \mu \mathrm{m}$ ) do not appear be a suitable food source for the small Strombidium spp. found in the bottom ice. Our budget estimate is based on particulate production only and does not account for the dissolved fraction. The underlying assumption is that the 
grazers in the ice were feeding on particulate material only. We cannot rule out the possibility that nematodes ingested dissolved matter, in which case the relative export of particulate matter through grazing (Table 4) should be revised downward. At the landfast ice station, the primary production diverted to dissolved organic carbon was, on average, $22 \%$ of the total (particulate + dissolved) production (Gosselin et al. unpubl.). New values for the export explained by meiofauna grazing in the bottom ice, if including the dissolved fraction of production, would be $2 \%$. This value does not differ much from that in Table 4 (2.6\%) and reflects the fact that the grazing pressure within the ice was negligible.

The estimate of the faecal carbon sinking flux only accounts for faeces produced by meiofauna, i.e. minipellets were not counted. This flux represented ca. One-third of the grazing estimate for bottom ice meiofauna. Assuming that all the pellets sinking at $1 \mathrm{~m}$ were produced in the ice, and that the carbon conversion factor used for the pellets is appropriate, the difference between bottom ice grazing and the faecal carbon flux would represent pellet accumulation in the bottom ice. There was a small accumulation of pheopigments in the bottom ice over the season $(0.11 \mathrm{mg}$ $\mathrm{m}^{-2}$ ), which yields (assuming a $30 \%$ degradation loss) a potential faecal carbon accumulation of ca. $12 \mathrm{mg} \mathrm{C}$ $\mathrm{m}^{-2}$. In order to balance meiofauna grazing (pellet production) with pellet accumulation in bottom ice and sinking, the actual degradation loss would have to be ca. $60 \%$. Variable pigment loss during copepod grazing has been reported in a number of studies. For example, Kleppel (1998) found substantial pigment loss (60 to 100\%) for pelagic copepods Acartia and Calanus, and Conover et al. (1986b) observed up to $90 \%$ pigment loss for Calanus in the Arctic. Other factors that could explain the difference between grazing and sinking faeces estimates are (1) the use of an inappropriate faeces carbon conversion ratio, (2) underestimation of faeces volumes, and (3) coprophagy and/or cophrorexhy, which would remove faeces during sinking, or a combination of these factors. While these factors cannot be resolved, the budget shows that $75 \%$ of the potential carbon export from the ice sank out without being grazed within the ice.

Since the bottom ice algal biomass was primarily exported via direct sinking into the water column, one could expect a very similar algal species composition in the sinking and the ice assemblages. The species observed were comparable; however, there were significant discrepancies in the relative contribution of dominant species within the sinking and the ice assemblages. Firstly, the strong dominance of Nitzschia spp. observed in the bottom ice was not mirrored in the traps and, secondly, abundances of Navic- ula spp. and Fragilariopsis spp. were higher in the traps than in the ice. If we assume that all unidentified diatoms in the traps were Nitzschia frigida, the relative contribution of this species (estimated range: 44 to $66 \%$ ) would still remain much lower than in the bottom ice. Differences in composition between the bottom ice and the sinking biomass have also been observed in Resolute Passage (Michel et al. 1996) as well as in McMurdo Sound, Antarctic (Leventer \& Dunbar 1987). These differences could be attributed to a number of factors, including differential sinking rates, grazing, or lateral advection. In McMurdo Sound, comparison of the diatom assemblages from the sea ice and shallow sediment traps suggests that delicate, thin-walled frustules are rapidly recycled in the upper water column (Leventer \& Dunbar 1987, Leventer 1998). While we cannot resolve the factors that contributed to differences in the ice and sinking assemblages, it appears that the diatom groups predominant in the sinking assemblage in the NOW, i.e. Navicula and Fragilariopsis, were also shown to accumulate in shallow traps in Resolute Passage (Michel et al. 1996). Fragilariopsis spp. are often found in sediment records and used as paleoindicator species in the Antarctic (see Leventer 1998), presumably due to the slow dissolution rates of their frustules (Smith \& Nelson 1985, Leventer 1998). Navicula spp. were abundant in the water column at the time of ice melt in the southeastern Hudson Bay, such that this diatom group could be susceptible to potential seeding of the phytoplankton bloom (Michel et al. 1993). At the time of this study, the phytoplankton in Smith Sound was largely dominated by flagellates, which made up $95 \%$ of the biomass near the bottom of the euphotic zone ( $1 \%$ of surface irradiance) and nearly $80 \%$ at the surface (Lovejoy et al. 2002). Other significant phytoplankton groups in Smith's Sound were dinoflagellates, and there was a very small contribution of Navicula septentrionalis and Fragilariopsis oceanica $(<1.5 \%)$ (Lovejoy et al. 2002). The phytoplankton bloom in the polynya was very strongly dominated by pelagic centric diatoms, i.e. Attheya septentrionalis, Thalassiosira spp., Coscinodiscus sp. (see Lovejoy et al. 2002). Hence, the contribution of land fast-ice algal species released into the water column did not appear to play an important role for phytoplankton development in the polynya.

\section{CONCLUSION}

Our results show that very little ice algal production was channelled through grazers within the ice. Consequently the major part of the biomass remained available for pelagic grazers, which would either feed directly at the ice undersurface or use the biomass after 
it is released into the water column. In the NOW area, ice algae represented only a small fraction of the total algal biomass (phytoplankton + ice algae), i.e. $<3 \%$ of total biomass at the stations visited (Gosselin et al. unpubl. data). In this context, the potential contribution of ice algal carbon to planktonic grazers is relatively modest in comparison to phytoplankton carbon available in the polynya. Nevertheless, in land fast-ice areas where ice algae constitute the bulk of the primary biomass during the spring, limited grazing within the ice can play a significant role in ensuring availability of ice algae for under-ice pelagic grazers, as well as for the benthic community. Our results suggest that, in addition to the timing of the release ice algae which is thought to be critical to ensure food availability to pelagic grazers (Michel et al. 1996), the composition of the ice community and food web interactions within the ice can play a significant role with respect to carbon transfer at the ice-water interface, in seasonally ice-covered areas.

Acknowledgements. This project was supported by a Research Network grant and by an individual research grant from the Natural Sciences and Engineering Research Council (NSERC) of Canada to M.G. During the expedition, the C.M.'s salary was paid from the central budget of the International North Water Polynya Study (NOW). Funding to T.G.N. was provided by the Carlsberg Foundation grant and the Danish Natural Science Council grant no. 9801391. The authors gratefully acknowledge the chief scientists and the Canadian Coast Guard officers and crew of the CCGS 'Pierre Esprit Radisson' for their invaluable support during the expedition. We also acknowledge the skilful support of the Polar Continental Shelf Project. We are indebted to M.-Eे. Garneau, P. Larouche, P. Lee, C. J. Mundy, and A. Weise for technical assistance in the field or in the laboratory. We also thank J.-Y. Anctil, B. LeBlanc and A. Gagné for logistical assistance, D. Bérubé for CHN analyses, and M. Simard and D. GrastrupHansen for cell identification and counts. We also thank 4 anonymous reviewers for helpful comments on the manuscript. This is a contribution to the research programs of the International North Water Polynya Study, the Freshwater Institute, and the Institut des sciences de la mer de Rimouski.

\section{LITERATURE CITED}

Agatha S, Spindler M, Wilbert N (1993) Ciliated protozoa (Ciliophora) from Arctic sea ice. Acta Protozool 32: 261-268

Anning JL (1989) The development and decline of the epontic algal community in Barrow Strait, NWT. Masters thesis, University of Guelph

Buck KR, Nielsen TG, Hansen BW, Gastrup-Hansen D, Thomsen HA (1998) Infiltration phyto- and protozooplankton assemblages in the annual sea ice of Disko Island, West Greenland, spring 1996. Polar Biol 20:377-381

Carey AG Jr (1985) Marine ice fauna: Arctic. In: Horner RA (ed) Sea ice biota. CRC Press, Boca Raton, FL, p 174-190

Carey AG Jr, Montagna PA (1982) Arctic sea ice faunal assemblage: first approach to description and source of the underice meiofauna. Mar Ecol Prog Ser 8:1-8
Conover RJ, Herman AW, Prinsenberg SJ, Harris LR (1986a) Distribution of and feeding by the copepod Pseudocalanus under fast ice during the Arctic spring. Science 232: 1245-1247

Conover RJ, Durvasula R, Roy S, Wang R (1986b) Probable loss of chlorophyll-derived pigments during passage through the gut of zooplankton, and some of the consequences. Limnol Oceanogr 31:878-887

Cota GF, Prinsenberg SJ, Bennett EB, Loder JW, Lewis MR, Anning JL, Watson NHF, Harris LR (1987) Nutrient fluxes during extended blooms of Arctic ice algae. J Geophys Res 92:1951-1962

Cota GF, Legendre L, Gosselin M, Ingram RG (1991) Ecology of bottom ice algae: I. Environmental controls and variability. J Mar Syst 2:257-277

Cross WE (1982) Under-ice biota at the Pond Inlet ice edge and in adjacent fast ice areas during spring. Arctic 35: $13-27$

Dodge JD (1985) Marine dinoflagellates of the British Isles. Her Majesty's Stationery Office, London

Dunbar IM (1969) The geographical position of the North Water. Arctic 22:438-441

Foissner W (1984) Taxonomy and ecology of some ciliates (Protozoa, Ciliophora) of saprobe systems. 1. Genera Litonotus, Amphileptus, Opisthodon. Hydrobiologia 119: 193-208

Garrison DL, Buck KR (1986) Organism losses during ice melting: a serious bias in sea-ice community studies. Polar Biol 6:237-239

González HE, González SR, Brummer GJA (1994) Short-term sedimentation pattern of zooplankton faeces and microplankton at a permanent station in the Bjoernafjorden (Norway) during April-May 1992. Mar Ecol Prog Ser 105: 31-45

Gosselin M, Legendre L, Demers S, Ingram RG (1985) Responses of sea-ice microalgae to climatic and fortnightly tidal energy inputs (Manitounuk Sound, Hudson Bay). Can J Fish Aquat Sci 42:999-1006

Gosselin M, Levasseur M, Wheeler PA, Horner RA, Booth BC (1997) New measurements of phytoplankton and ice algal production in the Arctic Ocean. Deep-Sea Res II 44: 1623-1644

Gradinger R (1999) Integrated abundance and biomass of sympagic meiofauna in Arctic and Antarctic pack ice. Polar Biol 22:169-177

Gradinger R, Zhang Q (1997) Vertical distribution of bacteria in Arctic sea ice from the Barents and Laptev Seas. Polar Biol 17:448-454

Gradinger R, Spindler M, Henschel D (1991) Development of Arctic sea-ice organism under graded snow cover. Polar Res 10:295-307

Gradinger R, Splinder M, Weissenberger J (1992) On the structure and development of Arctic pack ice communities in Fram Strait: a multivariate approach. Polar Biol 12: $727-733$

Gradinger R, Friedrich C, Spindler M (1999) Abundance, biomass and composition of the sea ice biota of the Greenland Sea pack ice. Deep-Sea Res II 46:1457-1472

Grainger EH (1977) The annual nutrient cycle in sea-ice. In: Dunbar M (ed) Polar oceans. Arctic Institute of North America, Calgary, p 285-299

Grainger EH, Hsiao SIC (1990) Trophic relationships of the sea ice meiofauna in Frobisher Bay, Arctic Canada. Polar Biol 10:283-292

Grainger EH, Mohammed AA, Lovrity JE (1985) The sea ice fauna of Frobisher Bay, Arctic Canada. Arctic 38:23-30

Haecky P, Andersson A (1999) Primary and bacterial produc- 
tion in sea ice in the northern Baltic Sea. Aquat Microb Ecol 20:107-118

Haecky P, Jonsson S, Andersson A (1998) Influence of sea ice on the composition of the spring phytoplankton bloom in the northern Baltic Sea. Polar Biol 20:1-8

Hansen B, Bjørnsen PK, Hansen PJ (1994) The size ratio between planktonic predators and their prey. Limnol Oceanogr 39:395-403

Hansen PJ, Bjørnsen PK, Hansen BW (1997) Zooplankton grazing and growth: scaling within the $2-2,000-\mu \mathrm{m}$ body size range. Limnol Oceanogr 42:687-704

Heinbokel JF (1978) Studies on the functional role of tintinnids in the Southern California Bight. II. Grazing rates of field populations. Mar Biol 47:191-197

Horner R, Ackley SF, Dieckmann GS, Gulliksen B and 6 others (1992) Ecology of sea-ice biota. 1. Habitat, terminology and methodology. Polar Biol 12:417-427

Hsiao SIC (1987) Sedimentation in Arctic Canada: species composition and biomass of phytoplankton contributed to the marine sediments in Frobisher Bay. Polar Biol 7: $245-251$

Hsiao SIC (1992) Dynamics of ice algae and phytoplankton in Frobisher Bay. Polar Biol 12:645-651

Jonsson PR (1986) Particle size selection, feeding rates and growth dynamics of marine planktonic oligotrichous cililates (Ciliophora: Oligotrichina). Mar Ecol Prog Ser 33: 265-277

Kleppel GS (1998) The fate of the carotenoid pigment fucoxanthin during passage through the copepod gut: pigment recovery as a function of copepod species and food concentration. J Plankton Res 20:2017-2028

Krainer KH, Foissner W (1990) Revision of the genus Askenasia Blochmann, 1895, with proposal of 2 new species, and description of Rhabdoaskenasia minima n.g., n.sp. (Ciliophora, Cyclotrichida). J Protozool 37:414-427

Kuosa H, Norrman B, Kivi K, Brandini F (1992) Effects of Antarctic sea ice biota on seeding as studied in aquarium experiments. Polar Biol 12:333-339

Lee PA, de Mora SJ, Gosselin M, Levasseur M, Bouillon RC, Nozais C, Michel C (2001) Particulate dimethylsulfoxide in Arctic sea-ice algal communities: the cryoprotectant hypothesis revisited. J Phycol 37:488-499

Legendre L, Ackley SF, Dieckmann GS, Gulliksen B and 6 others (1992) Ecology of sea ice biota. 2. Global significance. Polar Biol 12:429-444

Leventer A (1998) The fate of Antarctic sea ice diatoms and their use as paleoenvironmental indicators. In: Lizotte MO, Arrigo KR (eds) Antarctic sea ice: biological processes, interactions and variability. Antarct Res Ser 73: 121-135

Leventer A, Dunbar RB (1987) Diatom flux in McMurdo Sound, Antarctica. Mar Micropaleontol 12:49-64

Levinsen H, Nielsen TG, Hansen BW (2000) Annual succession of marine pelagic protozoans in Disko Bay, West Greenland, with emphasis on winter dynamics. Mar Ecol Prog Ser 206:119-134

Lovejoy C, Legendre L, Martineau MJ, Bâcle J, von Quillfeldt $\mathrm{CH}$ (2002) Distribution of phytoplankton and other protists in the North Water Polynya (Arctic). Deep-Sea Res II 49: 5027-5047

Lynn DH, Montagnes DJS (1988) Taxonomic descriptions of some conspicuous species of strobilidiine ciliates (Ciliophora: Choreotrichida) from the Isles of Shoals, Gulf of Maine. J Mar Biol Assoc UK 68:639-658

Lynn DH, Montagnes DJS, Small EB (1988) Taxonomic descriptions of some conspicuous species in the family Strombidiidae (Ciliophora: Oligotrichida) from the Isles of
Shoals, Gulf of Maine. J Mar Biol Assoc UK 68:259-276

Mathot S, Becquevort S, Lancelot C (1991) Microbial communities from the sea ice and adjacent water column at the time of ice melting in the northwestern part of the Weddell Sea. Polar Res 10:267-275

Melling H, Gratton Y, Ingram G (2001) Ocean circulation within the North Water Polynya of Baffin Bay. Atmosph Ocean 39:301-325

Menden-Deuer S, Lessard EJ (2000) Carbon to volume relationships for dinoflagellates, diatoms, and other protist plankton. Limnol Oceanogr 45:569-579

Michel C, Legendre L, Demers S, Therriault JC (1988) Photoadaptation of sea-ice microalgae in springtime: photosynthesis and carboxylating enzymes. Mar Ecol Prog Ser 50:177-185

Michel C, Legendre L, Therriault JC, Demers S, Vandevelde $\mathrm{T}$ (1993) Springtime coupling between ice algal and phytoplankton assemblages in southeastern Hudson Bay, Canadian Arctic. Polar Biol 13:441-449

Michel C, Legendre L, Ingram RG, Gosselin M, Levasseur M (1996) Carbon budget of sea-ice algae in spring: evidence of a significant transfer to zooplankton grazers. J Geophys Res 101:18345-18360

Mock T, Gradinger R (2000) Changes in photosynthetic carbon allocation in algal assemblages of Arctic sea ice with decreasing nutrient concentrations and irradiance. Mar Ecol Prog Ser 202:1-11

Moens T, Vincx M (2000) Temperature, salinity and food thresholds in 2 brackish water bacterivorous nematode species: assessing niches from food absorption and respiration experiments. J Exp Mar Biol Ecol 243:137-154

Moloney CL, Field JG (1989) General allometric equations for rates of nutrient uptake, ingestion and respiration in plankton organisms. Limnol Oceanogr 34:1290-1299

Montagnes DJS, Lynn DH (1991) Taxonomy of choreotrichs, the major marine planktonic ciliates, with emphasis on the aloricate forms. Mar Microb Food Webs 5:59-74

Montagnes DJS, Lynn DH, Roff JC, Taylor WD (1988) The annual cycle of heterotrophic planktonic ciliates in the waters surrounding the Isles of Shoals, Gulf of Maine: an assessment of their trophic role. Mar Biol 99:21-30

Nozais C, Gosselin M, Michel C, Tita G (2001) Abundance, biomass, composition and grazing impact of the sea-ice meiofauna in the North Water, northern Baffin Bay. Mar Ecol Prog Ser 217:235-250

Parsons TR, Maita Y, Lalli CM (1984) A manual of chemical and biological methods for seawater analysis. Pergamon Press, Toronto

Petz W, Song W, Wilbert N (1995) Taxonomy and ecology of the ciliate fauna (Protozoa, Ciliophora) in the endopagial and pelagial of the Weddell Sea, Antarctica. Stapfia 40

Runge JA, Ingram RG (1988) Underice grazing by planktonic, calanoid copepods in relation to a bloom of ice microalgae in southeastern Hudson Bay. Limnol Oceanogr 33: 280-286

Schnack-Schiel SB, Dieckmann GS, Gradinger R, Melnikov R, Spindler M, Thomas DN (2001) Meiofauna in sea ice of the Weddell Sea (Antarctica). Polar Biol 24:724-728

Scott CL, Falk-Peterson S, Sargent JR, Hop H, Lønne OJ, Poltermann M (1999) Lipids and trophic interactions of ice fauna and pelagic zooplankton in the marginal ice zone of the Barents Sea. Polar Biol 21:65-70

Scott CL, Falk-Petersen S, Gulliksen B, Lønne OJ, Sargent JR (2001) Lipid indicators of the diet of the sympagic amphipod Gammarus wilkitzkii in the Marginal Ice Zone and in open waters of Svalbard (Arctic). Polar Biol 24:572-567

Sime-Ngando T, Gosselin M, Juniper SK, Levasseur M 
(1997) Changes in sea-ice phagotrophic microprotists $(20-200 \mu \mathrm{m})$ during the spring algal bloom, Canadian Arctic Archipelago. J Mar Syst 11:163-172

Small EB, Lynn DH (1985) Phylum Ciliophora. In: Lee JJ, Hunter $\mathrm{SH}$, Bovee EC (eds) An illustrated guide to protozoa. Soc Protozool Spec Publ, Allen Press, Lawrence, KS, p 393-575

Smith REH, Anning J, Clement P, Cota G (1988) Abundance and production of ice algae in Resolute Passage, Canadian Arctic. Mar Ecol Prog Ser 48:251-263

Smith WO Jr, Nelson D (1985) Phytoplankton bloom produced by a receding ice edge in the Ross Sea: spatial coherence with the density field. Science 227:163-166

Song W, Wilbert N (2000) Ciliates from Antarctic sea ice. Polar Biol 23:212-222

Tanimura A, Hoshiai T, Fukuchi M (1996) The life cycle of the ice-associated copepod, Paralabidocera antarctica (Calanoida, Copepoda), at Syowa Station, Antarctica. Antarct Sci 8:257-266

Editorial responsibility: Fereidoun Rassoulzadegan, Villefranche-sur-Mer, France
Thomsen HA (1992) Plankton i de indre dansk farvande. Analyse af forekomsten af alger og heterotrofe protister (ekskl. Ciliater) i Kattegat. Havforskning fra Miljøstyrelsen bind 11. Miljøministeriet, Copenhagen (in Danish)

Tomas CR (ed) (1997) Identifying marine phytoplankton. Academic Press, London

Tremblay JÉ, Gratton Y, Carmack EC, Payne CD, Price NM (in press) Impact of large-scale Arctic circulation and the North Water Polynya on nutrient inventories in Baffin Bay. J Geophys Res

Utermöhl H (1958) Zur Vervollkommung der quantitativen Phytoplankton-methodik Internationale Vereinigung für theoretische und angewandte. Limnol Mitteil 9:1-38

Vézina A, Demers S, Laurion I, Sime-Ngando T, Juniper SK, Devine L (1997) Carbon flows through the microbial food web of first-year ice in Resolute Passage (Canadian High Arctic). J Mar Syst 11:173-189

Werner I (1997) Grazing of Arctic under-ice amphipods on sea-ice algae. Mar Ecol Prog Ser 160:93-99

Submitted: March 19, 2002; Accepted: July 25, 2002

Proofs received from author(s): October 28, 2002 